\title{
Impact of Government Facilities on Technical Efficiency of Rice Farmers in the Senegal River Valley
}

\author{
Kamu Tesislerinin Senegal Nehri Vadisi’ndeki Pirinç Çiftçilerinin Teknik Verimliliğine Etkisi
}

Cheikh Ahmadou Bamba NGOM

"Centre de Recherches Agricoles » of "Institut Sénégalais de Recherches Agricoles »/University Gaston Berger, Saint Louis, Senegal (shaixunabamba@hotmail.fr)

Keywords:

Agricultural Facilities Impact Assessment Senegal

River Valley

Technical Efficiencv

\begin{abstract}
This paper aims at assessing the impact of the government hydro-agricultural facilities on the rice farmers' technical efficiency in the Senegal River valley. Results estimations showed that farming in thesefacilities increaseson average the technical efficiency by $5.17 \%$. The technical efficiency determinants analysis from an exponential function estimation, using a nonlinear least squares method, reveals that, besides the treatment, the combined effects between this one and the distance from the house to the plot, the educations' level, the household sizeand the householder gender are statistically significant on efficiency. The major policy implications are:(i) the Government should keep on providing these kinds of agricultural infrastructure to farmers; (ii) the establishment of a sustainable Fund for Supporting Agricultural Research and Scaling out Agricultural Research Achievements would strengthen capacities of Research and Extension Services to address many issues in the rural areas.
\end{abstract}

\section{ÖZET}

Bu makale, devlethidro-tarımtesislerinin, Senegal Nehri vadisinde pirinç çiftçilerinin teknik verimi üzerindeki etkisini değerlendirmeyi amaçlamaktadır. Sonuçlara göre, bu tesislerde gerçekleştirilen zirai faaliyetler ortalama \%5,17 oranında teknik verimliliği arttırmaktadır. Lineer olmayan en küçük kareler yöntemini kullanarak üstel fonksiyon tahmininden teknik verimlilik belirleyicileri analizi, işleyişin yanısıra, ev ile arsa arasındaki mesafenin birleşik etkisi, eğitim seviyesi, hane halkı büyüklüğü ve aile içi cinsiyet, verimlilik açısından istatistiksel olarak önemlidir. Uygulanabilecek başlıca politikalar ise şunlardır: (i) Hükümet bu tür tarım altyapısını çiftçilere sunmaya devam etmelidir, (ii) Tarımsal Araştırma Destekleme ve Tarımsal Araştırma Başarılarını Ölçeklendirme için sürdürülebilir bir fon kurulması, Araştırma ve Genişletme Hizmetlerinin kırsal alanlardaki birçok konuyu ele alacak kapasitelerini güçlendirecektir. 


\section{INTRODUCTION}

As in almost all the Sub Saharan African countries, in Senegal, most of the consumed rice is imported. The local rice produced can only meet the national rice demand just for three months in a year. The rice imports in 2014 were estimated to $959,300.103 \mathrm{~kg}$ (AgenceNationale de la Statistique et de la Démographie, 2014) while local production of paddy for the entire country has reached $559,000.103 \mathrm{~kg}$ during the same year (statistics from FAO, 2015). Given a rice process rate estimated around $65 \%$, this local production, ifprocessed, would provide a volume close to $363,300.103 \mathrm{~kg}$ in white rice, ready to be consumed against a national rice demand laying beyond one hundred millionkilogrammes. With regards to this fact, the Senegal River Valley (SRV) has been targeted by policymakers to be a favourable geographical zone in response to the Government vision of establishing food self-sufficiency consideringthe physical and hydraulic potentials of this area.

To support irrigated crops, the Government used the National Domain Law to upgrade the Waalo'srainfed lands (Seck 1998, in Fall, 2008). Indeed, the entrance to the market economy and the intensification options of agricultural productions implemented in the "zones where water is controlled" led the State to put hydro agricultural infrastructure as partof the farming systemsin the SRV. These irrigated farming systems are built around the hydro agricultural facilities (Fall, 2008). Byhydro agricultural facility, we mean a landoriginally wild that afterward was cleared, levelled, bounded and on which an irrigation network has been set up. It is called Government facilityif done by the Government services; otherwise, it is called private facility. On average, from 2002 to 2011, the Government has spent annually USD 169,268,376 for agricultural facilities. By 2017, the "Programme de Relance et d'Accélération de la Cadence de l'AgricultureSénégalaise" (PRACAS), a component of the "Plan Sénégal Emergent" (PSE), started in 2014, is expecting to cover a total area of $331,300.104 \mathrm{~m} 2$ in rice farming. The global production of paddy expected is 1,600,000.103 kg (Ministry of Agriculture and of Rural Equipment, 2014).

The objective of this this paper is to assess the impact of the Governmenthydro agricultural facilities on the technical efficiency of the rice farmers in the SRV. To address the research issue, the sample has been divided into two subsamples: the subsample called "treated" comprises rice farmers operating in Government facilities whereas the subsample "control" refers to those who acts in private facilities. In the econometric model, the treatment status is a dichotomous variable which takes the value 1 if the producer is in a Government facility or 0 otherwise.

An overview regarding the literature allowed us to notice that some authors dealt with the impact assessment of the Government intervention on the technical efficiency both at the macroeconomic level (Percoco, 2004, Mastromarco and Woitek, 2006; Puig - Junoy and Pinilla, 2008; Alvarez - Ayusoet al. 2011) and in the agricultural research field (Taylor et al. 1986; Alene and Hassan, 2003; Ashkok and Balasubramanian, 2006; Jhaet al. 2007). However, most of them used time series macroeconomic data and/or performed an evaluation with parametric models. For those who used a comparative approach with two groups, their methodology was not robust to consider the observable and unobservable characteristics related to the members of each group. They should have prior made sure that the two groups are identical (or not) in terms of observable characteristics and the difference between the outcomes of the group is due to the treatment effect. If the programme exposure relies on some non-observable factors by the evaluator, then performing the instrumental variables method will be suitable. But, not mainstreaming these considerations can underestimate or overestimate the value of the parameters and alter their significance.

In the case of the SRV, up till now, there is a lack of microeconomic studies using recent impact assessment methodologies to measure the effect of these government facilities. This article aims at contributing to fill this gap of the literature in this domain by addressing the research issue mentioned above.

The rest of the paper is organised as follows: The next section describes the conceptual and methodological framework of the impact assessment; the third section presents the results of the estimations; the fourth section discusses the results achieved and the last section concludes the paper. 


\section{CONCEPTUAL and METHODOLOGICAL FRAMEWORK for IMPACT ASSESSMENT}

\subsection{The impact assessment principle}

The canonical model of assessing the effect of a treatment was introduced by Rubin in 1974. In this model (as known as the Rubin Causal Model (RCM)), evaluating the effect of a programme on an individual iassumes a comparison between two different situations that this individual is facing: he participates to the programme $(T=1)$ versus he doesn't $(T=0)$. Let Y1denoteshisoutcome ifhe is benefiting from the intervention and Y0if not. The treatment effect (D) is measured by the difference between these two outcomes $(\mathrm{D}=\mathrm{Y} 1-\mathrm{Y} 0)$. A fundamental assumption is considered regarding the RCM: the absence of externalities, that is to say a unit's treatment status does not affect another unit's outcome directly or through general equilibrium effects. This is called the Stable Unit Treatment Value Assumption (SUTVA). However, the fundamental issue of the causal inference is only one of these two situations can be observed (Holland, 1986). In other words, it's not possible to know, at the same time, what would be the outcome of someone if he was exposed to a treatment and his outcome if he hasn't participated (although the programme took place), vice versa. Another issue to get an individual causal inference is that the estimation is just done on a given sample instead of considering the entire population of interest (Chabet - Ferret, 2008). The observed outcome, function to the two potential outcomes (Y0 and Y1), can be written as follows: $\mathrm{Y}=\mathrm{TY} 1+(1-\mathrm{T}) \mathrm{Y} 0$. At this point, the evaluator is facing a missing data issue. Thus, as the difference cannot be computed for each person because of the missing data, the Average Treatment Effect (ATE), which is the impact of the intervention,is the mathematicalexpectation of the difference between the average outcomesfor the two groups (ATE $=\mathrm{E}(\mathrm{Y} 1-\mathrm{Y} 0))$; the Average Treatment Effect on Treated $(\mathrm{ATE} 1)=\mathrm{E}(\mathrm{Y} 1-\mathrm{Y} 0) \mid \mathrm{T}=1$. The comparison between the average outcomes of the two groups leads to this equilibrium: $\mathrm{E}(\mathrm{Y} 1-\mathrm{Y} 0)=\mathrm{E}(\mathrm{Y} 1 \mid \mathrm{T}=1)-\mathrm{E}(\mathrm{Y} 0 \mid \mathrm{T}=0)=\mathrm{E}(\mathrm{Y} 1 \mid \mathrm{T}=1)-\mathrm{E}(\mathrm{Y} 0$ $\mid \mathrm{T}=0)+\mathrm{E}(\mathrm{Y} 0 \mid \mathrm{T}=1)-\mathrm{E}(\mathrm{Y} 0 \mid \mathrm{T}=1)=\mathrm{E}(\mathrm{Y} 1 \mid \mathrm{T}=1)-\mathrm{E}(\mathrm{Y} 0 \mid \mathrm{T}=1)+\mathrm{E}(\mathrm{Y} 0 \mid \mathrm{T}=1)-\mathrm{E}(\mathrm{Y} 0 \mid \mathrm{T}=0)=\mathrm{ATE} 1+\mathrm{E}(\mathrm{Y} 0 \mid \mathrm{T}=$ 1) $-\mathrm{E}(\mathrm{Y} 0 \mid \mathrm{T}=0)=\mathrm{ATE} 1+$ selectionbias.

The selection bias resultsfrom a misspecification of the model or froman endogenous selection in the treatment. It occurs when the average situation of people who received the treatment was different from the average situation of those who didn't participate before the implementation of the programme.

\subsection{Presentation of the model}

This section accounts for the methodology used to evaluate the average effect of the fact of growing rice in aGovernment facility on the farmers' technical efficiency. Diagne (2014) reports about two fundamental types of attributes influencing the choice of the impact estimation method: the behavioural attribute and the population distribution or stochastic attribute. The first is related to what extent the population target units have control on receiving the treatment/intervention. If they have any control, then the treatment/intervention is endogenous. In case of they don't have any control, it is exogenous. The second attribute refers to how the receipt of the treatment is distributed within the population: randomly or not. By crossing these alternatives, four possible situations can be considered: the treatment is randomly distributed and exogenous; randomly distributed and endogenous; not randomly distributed and exogenous; not randomly distributed and endogenous. For each of these cases, an appropriate estimation method should be selected.

Considering its high hydraulic and socioeconomic potentials, the SRVis one of the most suitable area for rice farming in Senegal. Regarding the distribution of the plots located in the Government facilities, the SAED (the public society of rural development located in the SRV) proposes a distribution key to the rural councillorswho can validate or not. The farmer, after that will just receive a plot "ready for immediate occupation" and cannot, in any way, alter the plots distribution system. According to these considerations, we can assert that even though the treatment is not randomly distributed, the rice farmers don't have any control on the receipt of the treatment which is thus not randomly distributed and exogenous. At this point, the conditional independence assumption is invoked and according to Diagne (2014), ATE ATE1 ATE0 whereATE0 $=$ the Average Treatment Effect on untreated. Based on the justifications provided above, the propensity score matching method, which enables to get two similar groups in terms of observable characteristics, will be performed.

The matching method was initially proposed by Rubin in 1977. It pairs each individual treated with a control person displaying similar characteristics (Bassole, 2004). This technique assumes that, if there exists a $\mathrm{X}$ vector of covariates 
describing thetreatment and control groups, the selection bias due to $\mathrm{X}$ is zero approximately. This method rests upon the conditional independence assumption. This latter states that the assignment of the treatment is independent to the expected outcomes with condition to a certain number of observable covariates; and the error term is uncorrelated with the observable covariates.

However, this matching method is less accurate in the definition of the comparison group when the $\mathrm{X}$ vector of covariates are in a continuous form or when these characteristics become numerous. That is why Rosenbaum and Rubin (1983) proposed the propensity score matching (PSM) method to overcome this drawback. This methodis based on the conditional independence assumption stating the existence of a set of exogenous observed covariates, once controlled, make the treatment status independent from the potential outcomes. The idea is, within people of the sample displaying the same observable characteristics, the treatment effect is randomly distributed (Dontsop-Nguezet et al. 2011). The PSM stands forthe conditional probability of being involved in a treatment given a vector of observed covariates $\mathrm{Xi}$. If this score is properly defined, it can play the role of draw in randomised experiments. This score allows to balance the distribution of these covariates within the treatment and the control group. A suitable propensity score is a balancing tool for the distributions of the idiosyncratic variables (other than the outcome variables) in the treatment and the control group. Rosenbaum and Rubin's findings resulted in this following formulation for the propensity score:

$\mathrm{e}(\mathrm{X})=\mathrm{p}(\mathrm{T}=1 \mid \mathrm{X})(1)$

where $\mathrm{p}(\mathrm{T}=1 \mid \mathrm{X})$ stands for the probability for an individual ito participatein the programme conditional to its observed covariates.

Cox (1970) in Rosenbaum and Rubin (1983) asserted that the propensity score can often be modelled using an appropriate logit model or a discriminant score. He ended in this following equality:

$\mathrm{e}(\mathrm{X})=\mathrm{p}(\mathrm{T}=1 \mid \mathrm{X})=(\mathrm{p}(\mathrm{T}=1) \mathrm{p}(\mathrm{X} \mid \mathrm{T}=1)) /(\mathrm{p}(\mathrm{T}=1) \mathrm{p}(\mathrm{X} \mid \mathrm{T}=1)+\mathrm{p}(\mathrm{T}=0) \mathrm{p}(\mathrm{X} \mid \mathrm{T}=0))(2)$

One of the important advantages of this method isthat it is not necessary to specify a functional form for the outcome equation; thus, there is no risk to record a bias due to a misspecification of the model.

The PSMis also facing some drawbacks: it remains difficult to be performed because it rests upon the conditional independence assumption which is not easy to verify (Heckmanet al. 1998). The published literature about the propensity score is not very clear regarding the selection of the variables. This variables choice should be based on economic theory or empirical evidences related to the programme and its implementation process.

The explanatory variables selected for the impact assessment model are listed below:

For the treatment: The number of living years in the village, the place of living, the household size, the gender of the householder, the age of the householder, the matrimonial status "married", the distance between the plot and the house, the number of years of farming rice in the plot.

For the technical efficiency: The number of living years in the village, the household size, the gender of the householder, the age of the householder, the matrimonial status "married", the matrimonial status "single", the distance between the plot and the house, the number of years of farming rice in the plot, being illiterate, literate, primary school level, secondary school, higher education, Arabic, Koranic, Toucouleur ethnic group.

\section{PRESENTATION of the ESTIMATION RESULTS}

\subsection{Sampling methodology and data description}

Data were collected during a survey conducted under a project funded by the Japan International Cooperation Agency (JICA) and implemented by the "InstitutSénégalais de RecherchesAgricoles" (ISRA) in the Dagana and Podor departments (Saint Louis region) over the period from April to August 2012. 
Regarding the selection of the sites, a multi stage approach has been performedconsidering the production areas diversity and the crop systems heterogeneity. The first stage was to select the sites to investigate based on the features of the actors involved and their respective production system. With secondary data, the production areas have been characterised. The sites have been chosen among the most representative villages. The final step was to select randomly and to interview the observation units.

The survey involved 559 rice farmers. With a view to respect the conditional independence assumption stated earlier and make sure that treatment assignment is exogenous, those who rented plots in Governmentfacilities and those who used other forms of land appropriation not specified were ruled out the sample. Thus, the final sample records 467 rice farmers. Tables 1 and 2 in below compare some socioeconomic features between the two groups.

Table 1. Space and Socio-Economic Comparison Between the Treated and The Control Group

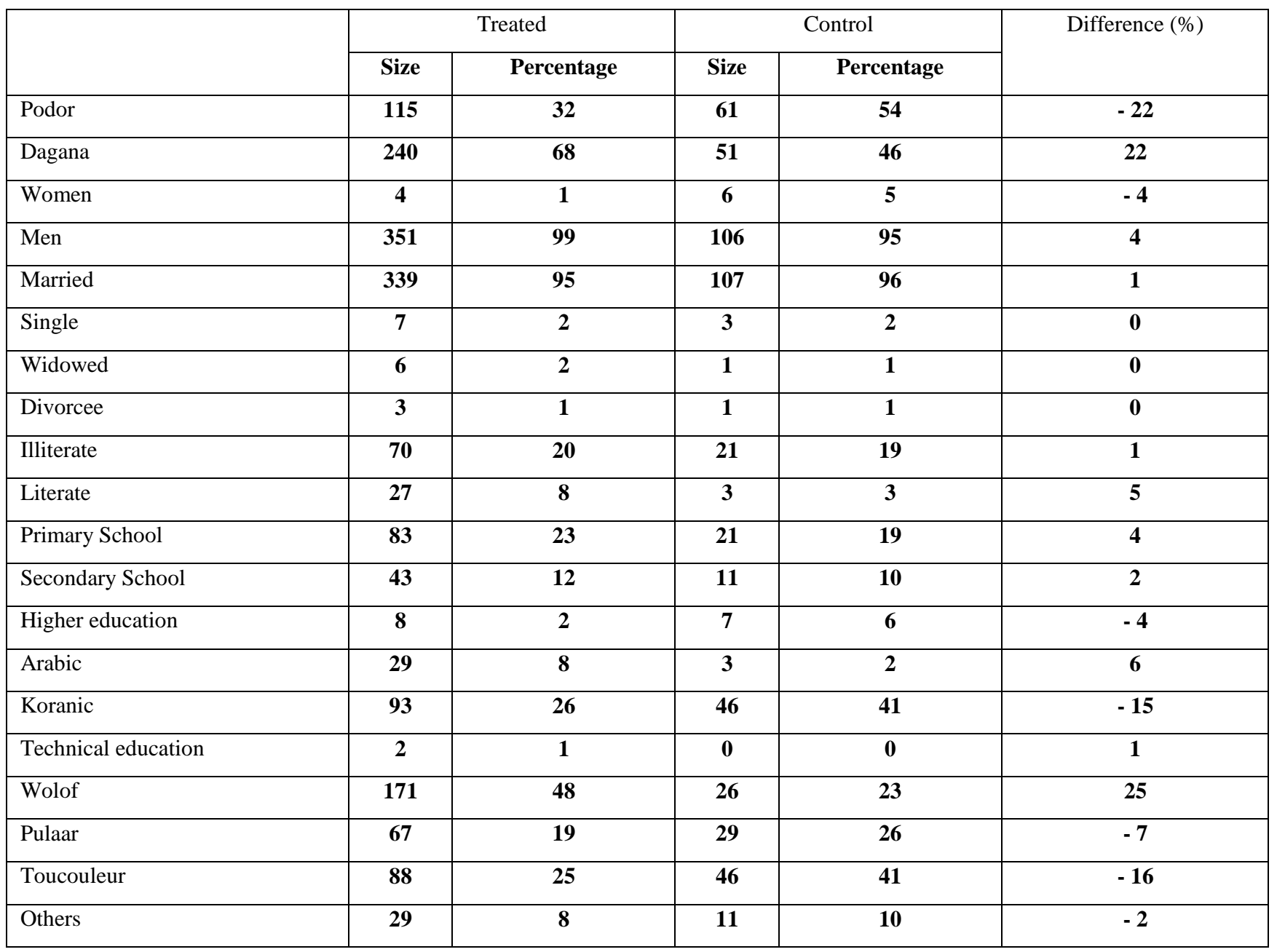

The sample of 467 units comprises 355 farmers operatingin the Government facilities, (representing $76 \%$ of the population) against 112 farmers growing rice in private facilities (24\% of the sample). The subpopulation of treated is dominated by men living in Dagana. The percentage of untreated people in Podor is higher than what is at Dagana. The ethnic group 
displays the same setting than the location where the Wolof ethnic group is most representative in the treatment group (like in Dagana) whereas most of the control group belongsto the Toucouleur ethnic group (like in Podor). Regarding the education status, most of the rice farmers (both in the treatment and the control group) attended the Koranic school.

Table 2. Comparison of Quantitative Variables Between the Two Groups

\begin{tabular}{|l|l|l|l|l|l|l|l|l|c|}
\hline \multirow{2}{*}{} & \multicolumn{4}{|c|}{ Treated } & \multicolumn{5}{c|}{ Control } \\
\cline { 2 - 10 } & Mean & SE & Min & Max & Mean & SE & Min & Max & \\
\hline Technical efficiency & $\mathbf{7 0 , 4 4}$ & 21,29 & 15 & 100 & $\mathbf{6 6 , 7}$ & 22,65 & 21 & 99 & 3,74 \\
\hline Yield (tons/ha) & $\mathbf{4 , 1 7}$ & 1,36 & 0,83 & 6,75 & $\mathbf{3 , 8 7}$ & 1,41 & 1,18 & 6,55 & 0,3 \\
\hline Household size & $\mathbf{1 0}$ & 5 & 1 & 26 & $\mathbf{1 0}$ & 6 & 1 & 38 & 0 \\
\hline Age & $\mathbf{4 7 , 6}$ & 13,86 & 17 & 86 & $\mathbf{4 6 , 3 1}$ & 13,61 & 20 & 80 & 1,49 \\
\hline Distance (km) & $\mathbf{4 , 2 1}$ & 3,99 & 0,03 & 39 & $\mathbf{6 , 2 4}$ & 7,48 & 0,2 & 52,7 & $-2,03$ \\
\hline Years of farming rice in the plot & $\mathbf{1 4 , 2 2}$ & 9,14 & 1 & 42 & $\mathbf{1 2 , 4 6}$ & 8,08 & 2 & 34 & 0,96 \\
\hline
\end{tabular}

Considering the outcome variable, the seminal works about efficiency were attributed to Koopmans (1951) and Debreu (1951). Later Farrell (1957) made the difference between the technical and allocative efficiency concepts. According to the latter, the efficiency of a firm means its success in producing as large as possible an output from a given set of inputs (output expanding oriented). It can also be considered as the capacity of a firm to achieve a given level of output using inputs as small as possible (input saving oriented). The estimation of a stochastic production function by the maximum likelihood method enabled to get technical efficiency scores for rice farmers in the sample ranging between 15 and $100 \%$ with an average of $70 \%$.

Before validating the model and starting the interpretation of the estimations results, it's important to perform a crucial test. This latter, called balancing test, enable to know whether, for a given propensity score, the distribution of the observable and unobservable characteristics is similar within the treatment and the control group (Xie et al. 2011). If the balancing test is satisfied, it means that for a given propensity score, the treatment assignment is randomly distributed and in this case, the characteristics of the units in the treatment group would be similar, on average, with those of the units in the control group (Becker and Ichino, 2002). The results of the estimations show that the balancing test is satisfied.

\subsection{The Average Treatment Effect (ATE) Method}

The ATE approach enables to minimise the selection bias induced by the observed covariates. This method is performed in two steps. First, we do a sampling which leads us to get a control group smaller in size than the initial one where the distribution of the observable characteristics is similar to what we have in the treatment group. This matching is operated by the propensity score which determines the probability to participate into the programme. This score is estimated using a probit model. Secondly, the ATE, ATE1 and ATE0 are estimated using a non-parametric estimation approach. The determinants of the treatment are got by running a probit model and those of the outcome variable are computed by estimating an exponential functional form by the nonlinear least squares method. The table 3 below displays the results of the determinants for the treatmentvariable.

\footnotetext{
${ }^{1}$ Standard Error
} 
Table 3. Estimation of the treatment determinants

\begin{tabular}{|c|c|c|}
\hline & Coefficient & SE \\
\hline Years of living in the village & $0,012 *$ & 0,007 \\
\hline Household size & $-0,001$ & 0,014 \\
\hline Age of the householder & $-0,005$ & 0,008 \\
\hline Matrimonial Status « married » & $-0,21$ & 0,337 \\
\hline Distance between the house and the plot & $-0,044 * * *$ & 0,013 \\
\hline Pseudo $\mathrm{R}^{2}$ & $8,66 \%$ & \\
\hline
\end{tabular}

*** Significant at $1 \%$

** Significant at $5 \%$

* Significant at $10 \%$

The table 4 shows the results of the estimation by the nonlinear least squares method of the technical efficiency determinants using an exponential functional form.

Table 4. Estimation of the Technical Efficiency Determinants

\begin{tabular}{|c|c|c|}
\hline & Coefficient & SE \\
\hline Treatment Status (TS) & $0,077 * *$ & 0,037 \\
\hline TS * Years of living in the village & $-0,001$ & 0,002 \\
\hline TS $*$ Household size & $-0,007 * *$ & 0,003 \\
\hline TS * Gender & $-0,201 *$ & 0,109 \\
\hline TS * Age & 0 & 0,002 \\
\hline TS * Distance between the house and the plot & $0,008 * * *$ & 0,003 \\
\hline TS $*$ Number of years in farming rice & $-0,001$ & 0,002 \\
\hline TS * Matrimonial Status « married » & 0,125 & 0,114 \\
\hline TS * Matrimonial Status « single » & 0,1 & 0,15 \\
\hline TS * Illiterate & $4,241 * * *$ & 0,134 \\
\hline TS $*$ Literate & $4,305 * * *$ & 0,146 \\
\hline TS $*$ Primary school level & $4,41 * * *$ & 0,136 \\
\hline TS * Secondary school & $4,327 * * *$ & 0,139 \\
\hline TS $*$ Higher education & $4,302 * * *$ & 0,155 \\
\hline TS * Arabic & $4,359 * * *$ & 0,146 \\
\hline TS * Koranic & $4,327 * * *$ & 0,139 \\
\hline TS * Toucouleur ethnic group & $-0,031$ & 0,04 \\
\hline Adjusted $\mathrm{R}^{2}$ & $91,22 \%$ & \\
\hline
\end{tabular}

The table 5 presents the average treatment effects computed within theentire population, the subpopulation of treated and of untreated.

Table 5. Estimation of the average treatment effects on technical efficiency

\begin{tabular}{|c|c|c|}
\hline & Coefficient & Robust Standard error \\
\hline ATE & $5,2 * *$ & 2,48 \\
\hline ATE1 & $5,17 * *$ & 2,45 \\
\hline ATE0 & $5,32 * *$ & 2,55 \\
\hline PSB $^{2}$ & $-0,04$ & 0,03 \\
\hline
\end{tabular}

2 Population Selection Bias 
The table 6 deals with the average effects estimated within the two subsamples of men and women.

Table 6. Comparison of the average treatment effects on technical efficiency between the men and women subsamples

\begin{tabular}{|l|c|c|c|c|}
\hline \multirow{2}{*}{} & \multicolumn{2}{|c|}{ Men } & \multicolumn{2}{c|}{ Women } \\
\cline { 2 - 5 } & Coefficient & Robust SE & Coefficient & Robust SE \\
\hline ATE & $5,2 * *$ & 2,47 & $5,64 * *$ & 2,81 \\
\hline ATE1 & $5,17 * *$ & 2,45 & $5,45 * *$ & 2,7 \\
\hline ATE0 & $5,29 * *$ & 2,53 & $5,76 * *$ & 2,89 \\
\hline PSB & $-0,03$ & 0,03 & $-0,18$ & 0,25 \\
\hline MEANDIFF & 4,07 & 2,49 & $-0,25$ & 10,72 \\
\hline
\end{tabular}

\section{DISCUSSION}

Regarding the interpretation of the estimation results for the treatment determinants (table 3), apart from the household size, theage and matrimonial status of the householder, all the explanatory variables recorded coefficients statistically significant. The household size is more determinant in the area to be allocated to the household rather than in the process of getting a plot in a Government facility. The results achieved confirm the plots distribution system. Indeed, the Government facility developed is distributed within farmers living around this area. That is why the more we live in these villages for long, the more we are likely to benefit from a plot (positive coefficient of the variable years of living in the village), as well as living in Dagana (positive coefficient of the variable place of living). Being far from the facility (negative coefficient of the variable distance between the house and the plot) plays negatively forgetting a plot in a government facility. The variable gender recorded a positive coefficient. It means that men householders are likely in a better position to have a plot in Government facility than women householders.

The table 4 displays the results of the combined effect between the treatment variable and each of the explanatory variables. The treatment status taken apart and when combined with the distance between the house and the plot, and the different education levels, present positive coefficients significantly different from zero. When it is combined to the household size andthe householder gender, the effectsare statistically significant and negative.

The treatment status has recorded a positive coefficient statistically significant. This means that cropping in a Government facility has a positive effect on technical efficiency. This finding is consistent insofar as the selection of the areas to develop is not random. In most of the cases, these Government facilities are settled on kinds of soils named "hollaldé" which are the more suitable lands for rice. Because of their permeability, they can keep humidity for long necessary for a good growth of the rice plant. In addition, Government facilities comprise mostly irrigation and drainage channels facilitating the entry and the exit in the plot of the water coming from the river. This ensures a water control for the plot. The private facilities conception as well as their drainage system are done basically. This fact gives a comparative advantage to the farmer acting in a Government facility.

Considering the combined effect of the distance between the house and the plot, if s/he wants to achieve a good agricultural performance, the farmer must spend the suitable time to complete properly the different stagesof the technical pathway from the land preparation to the crop bagging. That means a continuous presence in the field. Some producers, having their plots located far from their living village, spend all the day in the field. They take this opportunity to focus deeper on the agricultural activities whereas those who are living close to their plot seem to be more independent. Thus, it is the distance which enables the farmer to spend enough time for the different steps in the technical pathway and this additional time has a positive effect on technical efficiency.

Regarding the education levels, what is important to noticeis the fact of being illiterate, when combined to the treatment status, is positively correlated to the outcome variable. Which goes somehow against what is found in the literature.

${ }^{3}$ Means Difference 
However, in the case of this research, the issue is to analyse the combined effect of being illiterate and cropping in a Government facility on the technical efficiency. The result discovered can be explained by the fact that the mean producer (referring to the mean age) operating in a Government facility has experienced the period before the establishment of the New Agricultural Policy $(1960-1983)$ when farmer in the SRV was closely trained and supervised by the SAED. This enabled him to learn how to grow rice just by doing regardless its education level. In addition, rice farming and the management of these facilities require some given skills that farmers got over the years. For the other levels of education, as said earlier, although most of the training sessions are done in local language, but being literate enablesthe farmer to get accustomed quickly with new technologies and innovations. This can also increase the probability of adopting new technologies and choosing suitable quantities of inputs.

For the combined effect of the household size, it is important to mention that its effect on productivity depends on the skills and capabilities of the members (Ogundele and Okoruwa, 2003). If they have achieved a certain level of education and/or have got a good experience in rice growing, then they can effectively support the head of the household. Unfortunately, in the SRV, as stated earlier, the family workforce comprises people who learnt how to grow rice just by doing and sometimes are not sensitised on good practices required to achieve high yields.

Regarding the combined effect of the householder gender, what we found after investigations, is that women spend much time in the fields than men and they perform most of the farm activities even in the plots owned by men. They better master farm practices than men and they are more dynamic within farmers' organisations.

Considering the results of the impact assessment of Government facilities on technical efficiency in table 5, the ATE1 parameter shows that, on average, cropping rice in a Government facility increases the technical efficiency by $5.17 \%$. This result is a relevant finding insofar as the means difference method dealt with a non-statistically significant parameter. Indeed, the comparison made in the table 2 displays a difference of $3.74 \%$ between the average outcomes of the treated and the control group. The significance test performed states that the difference is not statistically different from zero. In other words, an analysis based on this kind of estimation would conclude that the fact of growing rice in a Governmentfacility has no effect on the farmers' technical efficiency in this area.

The ATE parameter is measuring the programme effect if it has been extended to the entire sample. The value recorded (5.2\%) is greater than the ATE1.The ATE0 expresses the average treatment effect within the control subsample if they had cultivated in Government facilities. The value of the coefficient (5.29\%) is greater than the first two ones. The ATE and ATE0 are critical because they enable to formulate policy implications in favour of the extension of the Government facilitiesto non-beneficiaries' population. The Population Selection Bias (PSB) computes the gap between the ATE1 and the ATE. The coefficient is statistically non-significant. This means that the control group situation is a good counterfactual to the one of the treated group.

The table 6 shows that the means difference method displays non-significant results for both the men and women groups. Regarding the ATE method, all parameters are significant at 5\% level. It can be noticed that performances achieved within the women are greater than the ones within the men group. This would imply that the treatment has more important effect on women than on men although the first group comprises a little number of persons.

For both the two groups, the treatment effect on the untreated population is greater than the other ones computed. This leads to large opportunities for extending the programmeto women and men non-beneficiaries.

\section{CONCLUDING REMARKS}

This research dealt with the impact assessment of Government hydro-agricultural facilities on technical efficiency of rice farmers in the Senegal River Valley.The estimations results showed that cropping rice in a Government facility increases, on average, the technical efficiency by $5 \%$. The first policy implication coming up at this point is that Government authorities should not leave the private sector to take care of the issue of developing these agricultural facilities. This implication formulated is more strengthened by the ATE0 value which lays above the ATE1 and the ATE. In the perspective of improving technical efficiency of rice farmers in this northern part of the country, what is strongly suggested is to scale out this Government programmebyinvolving the maximum of non-beneficiaries. Another policy implication 
refers to the renewalof these facilities and the servicing of the hydro-agricultural equipment because their obsolescence over the years decreases their performance.

The disaggregation of the sample according to the gender approach shows that the treatmenthas greater effect on women than on men. This implies that it would be better to operate a positive discrimination in favour of women so that they will have a better access to land. What should be undertaken is to allocate to women a specific area in the Government facilities and to consideramong others the main activity, the experience in agriculture, and the ownership of plots by a husband or a parent as plot assignment criteria.

The last advocacy is dedicated to policymakers to provideenough financial means to research and extension institutions. Indeed, the lack of training in all steps along the production process is a major constraint for farmers in achieving good agricultural performances. However, only these institutions have technical competences to address this issue. Unfortunately, they are facing financial and logistic constraintsthat limit their intervention on the field. The establishment of a sustainable Fund for Supporting Agricultural Research and Scaling out Agricultural Research Achievements [F2(SAR)A] would provide more technical and financial support to research and extension institutes so that they will better deliver results that people are expecting.

\section{REFERENCES}

Agence Nationale de la Statistique et de la Démographie. (2014). Note d'Analyse du Commerce Extérieur. Ministryof Economyand Finances of Senegal.

ALENE, A.D. \& HASSANI, R. M. (2003). Measuring the Impact of Ethiopia's New Extension Programme on the Productive Efficiency of Farmers. Contributed paper selected for presentation at the 25th International Conference of Agricultural Economists, August, Durban, South Africa.

ALVAREZ - AYUSO, I.C., BECERRIL - TORRES, O. U. \& del MORRAL - BARRERA, L. E. (2011). "The Effect of Infrastructures on Total Factor Productivity and its Determinants: A Study on Mexico”. Economic Studies, 26(1), January - June: 97 - 122.

ALTINOK, M., SAÇLI, C., (2009). “Toplam Kalite Yönetiminin Verimliliğe Etkisi-Panel Mobilya Üreten Bir İşletmede Çerçeve Uygulama". SÜ İïBF Sosyal ve Ekonomik Araştırmalar Dergisi, 18: 63-86.

ASHKOK, K.R. \& BALASUBRAMANIAN, R. (2006). Role of Infrastructure in Productivity and Diversification of Agriculture, Draft Final Report, South Asia Network of Economic Institutes (SANEI).

BASSOLE, L. (2004). Programme d'infrastructures rurales et bien-être des ménages: Analyse en termes d'indicateurs anthropométriques des enfants. Unpublished paper, CERDI - CNRS, Universitéd'Auvergne.

BECKER, S.O. \&ICHINO, A. (2002). "Estimation of average treatment effects based on propensity scores". The Stata Journal, 2(4): 358 -377 .

CHABE - FERRET, S. (2008). L'évaluation de l'impact des politiques publiques: caractérisation des enjeux et exemples de politiques agricoles et forestières. Unpublished doctoral dissertation, Universitéd'Auvergne Clermont-Ferrand I, France.

COX, D.R. (1970). The Analysis of Binary Data. London: Methuen \& Co Ltd.

DEBREU, G. (1951). “The Coefficient of Resource Utilization”. Econometrica, 9(3) July: 273-292.

DIAGNE, A. (2014). Impact Assessment Methodology. Presentation made at the Africa Rice Center Headquarters, Cotonou, Benin.

DONTSOP-NGUEZET, P.M., DIAGNE, A, OKORUWA, V. O. \& OJEHOMON, V. (2011). Impact of Improved Rice Technology on Income and Poverty Among Rice Farming Household in Nigeria: A Local Average Treatment Effect (LATE) Approach.Contributed paper prepared for the 25th conference of the Centre for the Studies of African Economies (CSAE), March, St Catherine College, University of Oxford, UK.

FALL, A. A. (2008). Impact du crédit sur le revenu des riziculteurs de la Vallée du Fleuve Sénégal. Unpublished doctoral dissertation, Universityof Montpellier I, France.

FARREL, M. J. (1957). "The measurement of productive efficiency". Journal of the Royal Statistical Society: Series A (General), 120(3): $253-290$. 
HECKMAN, J. J., ICHIMURA, H. \& TODD, P. (1998). "Matching As An Econometric Evaluation Estimator". Review of Economic Studies, 65: $261-294$.

HOLLAND, P.W. (1986). "Statistics and Causal Inference”. Journal of the American Statistical Association, 81: 945-970.

JHA, R. K, GYAWALI, L. N., REGMI, A. P., GHIMIRE, A. \& PAUDYAL, K. R. (2007). Impacts of participatory extension programme on technical efficiency of farmers in Nepal. Unpublished paper, South Asia Network of Economic Institutes (SANEI).

KOOPMANS, T. C. (1951). Analysis of production as an efficient combination of activities. In Cowles Commission for Research in Economics (Ed.), Activity Analysis of Production and Allocation. John Wiley \& Sons, Inc., New York.

MASTROMARCO, C. \& WOITEK, U. (2006). "Public infrastructure investment and efficiency in Italian regions". Journal of Productivity Analysis, 25:57-65.

Ministère de l'Agriculture et de l'Equipement Rural du Sénégal, 2014.Programme d'Accélération de la Cadence de l'Agriculture Sénégalaise (PRACAS): Les Priorités à l'horizon 2017. Unpublishedpaper.

NGOM, C. A. B., SARR, F. \& FALL, A. A. (2016). "Mesure de l'efficacité technique des riziculteurs du bassin du fleuve Sénégal". Economie Rurale: numéro, 355, septembre - octobre: 91 - 108.

OPARA, U. N. (2010). "Personal and Socio-Economic Determinants of Agricultural Information Use by Farmers in the Agricultural Development Programme (ADP) Zones of Imo State, Nigeria”. Library Philosophy and Practice: $1-8$.

PERCOCO, M. (2004). "Infrastructure and Economic Efficiency in Italian Regions”. Networks and Spatial Economics, 4: $361-378$.

PUIG-JUNOY, J. \& PINILLA, J. (2008). Why Are Some Spanish Regions So Much More Efficient Than Others? Unpublished paper.

QUATRIDA, D. (2009). La SAED face aux privés: problèmes et perspectives de l'agriculture irriguée dans le Delta du fleuve Sénégal.InDansero, E, Luzzati, E\&Seck, SM(Ed.), Organisation paysanne et développement local, leçon à partir du cas du Delta du fleuve Sénégal.L'Harmattan, Italia.

ROSENBAUM, P. R. \& RUBIN, D. B. (1983). "The Central Role of the Propensity Score in Observational Studies for Causal Effects". Biometrika, 70(1): $41-55$.

RUBIN, D. B. (1974). "Estimating Causal Effects of the Treatments in Randomized and Nonrandomized Studies". Journal of Educational Psychology, 66(5): $688-701$.

RUBIN, D. B. (1977). “Assignment to Treatment Group on the Basis of a Covariate”. Journal of Educational Statistics, 2: 1-26.

SECK, S. M. (1998). Sécurité et insécurité foncières dans les systèmes du domaine national et de la privatisation: Quelques Éléments de Réflexion autour de la Vallée du Sénégal.In Séminaire sur la Sécurité Foncière au Sénégal, PSI-CORAF à St-Louis du 1er au 3 avril.

TAYLOR, T. G., DRUMMOND, H. E. \& GOMES, A. T. (1986). “Agricultural credit programmes and production efficiency: an analysis of traditional farming in southeastern Minas Gerais, Brazil”. Am. J. Agric. Econ, 68: 110-119.

XIE, Y., BRAND, J. \& JANN, B. (2011). Estimating Heterogeneous Treatment Effects With Observational Data. Report 11 - 729 , Population Studies Center, University of Michigan Institute for Social Research, USA 